\title{
Bentham's Place in English Legal History
}

\section{Sir William Holdsworth*}

ToHn StUART MIIL said of his father, James Mill, that he was "the $J$ last of the eighteenth century." Bentham, who died in 1832, four years before James Mill, can, with quite as much truth, be regarded as the last but one of the eighteenth century; for, as Dicey has said, "he was in spirit entirely a child of the eighteenth century, and in England was the best representative of the humanitarianism and enlightenment of that age." Like other representative men of that century, he believed in its intellectual superiority to all other centuries. ${ }^{3}$ Like them, he was prepared to apply a reasoned criticism of an analytical kind to laws and institutions and to projects for reforming them; ${ }^{4}$ and he was not prepared to attach weight to arguments for delaying such projects for reforms which were founded upon historical explanations of the genesis of these rules and institutions. As we might expect, he scorned Savigny's German historical school. In 1830 he wrote: 5

"It is not every man that knows, that by this same school a history of law is spoken of,- and with no small assurance,-as a most advantageous substitute to law itself: ... and that, by these philosophers, it is mentioned with perfect sincerity, and no small earnestness, that by an historical work of this sort, direction sufficient may be given to the political conduct of men in that same country."

His dislike of governmental interference with individual liberty was shared by many representative men in the eighteenth century. ${ }^{6}$ If the result was a weak government, which was unable to perform the duties which changing social conditions placed upon it, Bentham

*K.C., D.C.L., Hon. LL.D. Vinerian Professor in English Law, University of Oxford; Fellow of All Souls College, Oxford; Hon. Fellow of St. Jolnn's College, Oxford. Author of History of English Law (1922); Historical Introduction to Land Law (1927); and of numerous other publications.

1 AUTOBIOGRAPEY (4th ed. 1874) 204.

2 Lectures on the Relation Between Law and Public Optnion in England (2d ed. 1914) 128.

310 Holdsworth, History of ENglish Law (1922) $5-6 ; 11$ ibid. $278 ; 12$ ibid. $729-30$.

410 ibid. $113 ; 12$ ibid. 729-30.

54 BENTHAM, WORKS (Bowring's ed. 1843) 425.

6 E.g., by Jolinson (10 HoldSWORTH, op. cit. supra note 3, at 419,454 n. 8 ; 11 ibid. 284), and Blackstone (10 ibid. 419, 420). 
was prepared, in his earlier years, to eke out its deficiencies by a recourse to the expedient of contracting with an individual or a corporation for their performance. We shall see that lis principle of utility was then generally accepted as the test by which new legislative proposals ought to be tried. ${ }^{7}$

These intellectual characteristics Bentham shared with many of his eighteenth century contemporaries. But he had other and more important intellectual clraracteristics which caused him to differ profoundly from them. The majority of Englishmen were contented with the balanced eighteenth century constitution, and with the main principles of the law on wlicl it rested..$^{8}$ Its inconveniences and anomalies were, they thought, a small price to pay for the advantages which it secured to them. In the opinion of many they were hallowed by their antiquity, and, therefore, they thought that it was the duty of good citizens to understand their constitution and their law according to their measure, and to venerate when they were not able presently to comprehend. ${ }^{9}$ Paley was as convinced a believer in the utilitarian philosoplry as Bentham; but, like Burke, he venerated the British constitution, and lie used his philosophy to defend its anomalies. ${ }^{10}$ Similarly Blackstone, though he made many suggestions for the reform of the law, is its convinced admirer; and he used lis knowledge of its underlying principles and the reasons on which they were based to defend effectively principles and rules and institutions which could not be defended by a believer in the sole authority of the utilitarian principle and all its logical consequences. ${ }^{11}$ It is at this point that Bentham parted company with these eighteenth century lawyers and plilosopliers. Bentham was not contented with English law and English institutions, and he was a believer in the sole authority of the utilitarian principle and all its logical consequences. Therefore, unlike them, he did not recognize Horace Walpole's distinction between the correction of abuses and the removal of landmarks ${ }^{12}$ - a distinction whicl was emphasized by Burke. ${ }^{13}$

7 See p. 572, infra.

810 HoldswortH, op. cit. supra note 3 , at $11 ; 11$ ibid. 278.

93 BURRE, WORKS (Bohn's ed. 1889) 114.

10 Dicey, op. cit. supra note 2, at 143 ; Halévy, The Growtin of Phinosophic RAdICALISM (1928) 80-81; cf. 10 Holdsworth, op. cit. supra note 3 , at 633 , for his view of the advantages of the influence which the state of the representation enabled the King and the House of Lords to exercise over the House of Commons.

11 12 HoLDSWORTH, op. cit. supra note 3, at 728-30, 734-35.

1213 LetTers OF Horace WaLPole (Toynbee's ed. 1903) 86.

136 BUREE, op. cit. supra note 9, at 152, cited 10 HoLDSWORTH, op. cit. supra note 3 , at $113 \mathrm{n} .1$. 
There was no limit to Bentham's critical analysis of existing laws and imstitutions, and of his application to them of his principle of utility; and it was his method of analysing and applying in detail the results of his analysis to English laws and institutions which justifies his title to be considered an original thinker. Take, for instance, the example given by Dicey: ${ }^{14}$

"At the time when Bentham became the preacher of legislative utilitarianism the English people were proud of their freedom, and it was the fashion to assert, that under the Enghsh constitution no restraint, which was not requisite for the maintenance of public order, was placed on individual liberty. Bentham saw through this cant, and perceived the undeniable truth, that, under a system of ancient customs modified by haphazard legislation, unnumbered restraints were placed on the action of individuals, and restraints which were in no sense necessary for the safety and good order of the community at large, and he inferred at once that these restraints were evils."

He applied this criticism in detail to all the principles and rules of English law, and so he was, as Mill has said, "the great questioner of thimgs established."15

"If the superstition about ancestorial wisdom has fallen into decay; if the public are grown familiar with the idea that their laws and institutions are in great part not the product of intellect and virtue, but of modern corruption grafted upon ancient barbarism; if the hardiest innovation is no longer scouted because it is an iunovation-establishments no longer considered sacred because they are estabhishments-it will be found that those who have accustomed the public mind to these ideas have learnt them in Bentham's school, and that the assault on ancient institutions has been, and is, carried on for the most part witll his weapons."16

It is not only the thoroughness with which Bentham exposed the abuses and anomalies which existed in the English legal system, it is not only the thoroughness with which he applied the principle of utility to test the soundness of all laws and institutions, which gives him so great a place in English legal history; it is also the means which he advocated for the reform and restatement of the law. Abuses and anomalies must be removed and the law must be reformed and restated by the direct action of the legislature. These three things-his method of exposing abuses, his application of the primciple of utility, and his advocacy of the direct action of the leg-

14 Op. cit. supre note 2 , at 147.

$151 \mathrm{Mmx}$, Dissertations and Discussions (2d ed. 1867) 332.

$16 \mathrm{Ibid}$. at 333. (Italics added.) 
islature-are his titles to fame as a legal theorist and a reformer of the law. Many others saw the need for reform; but he alone had both the industry and the capacity to elucidate the principles upon which the many reforms needed in all branches of the law should be made, to make concrete suggestions as to the shape which these reforms should take, and to prove that it was the duty of the legislature to enact the laws needed to give effect to them. It is these qualities and these achievements which entitle him to his fame as a legal philosopher. They have made him, in spite of his intellectual affinities with eighteenth century thinkers, the pioneer of the age of law reform.

But we must not underrate the effects of Bentham's intellectual affinities with eighteenth century thinkers. It is because Bentham combimed these intellectual affinities with the intellectual characteristics which made him the pioneer of the age of law reform that he has exerted so great an influence upon the development of English law in the mineteenth century and down to the present day. It is the extent of this influence which gives to him and his ideas so large a place in this latest phase of our legal history. The causes of this influence have been acutely analysed by Dicey in his Law and Opinion. They can be summarized as follows:

First, when, in the second and third decades of the mineteenth century, the majority of thinking men were beginning to realize that the law and institutions of England required a thorough reform, Benthain supplied them with an ideal and a programme. Neither were revolutionary and both were intelligible.

"Even the prosaic side of Bentham's doctrines, which checks the sympathy of modern readers, reassured sensible Englishmen who in 1830 liad come to long for reform but dreaded revolution. Bentham and his friends might be laughed at as pedants, but were clearly not Jacobins [revolutionists]; and, after all, whatever were the defects of Bentham as a jurist, critics who really understood his life and work knew that the first of legal philosophers was no agitator, but a systematic thinker of extraordinary power, and a thinker who kept his eyes fixed, not upon vague and indefinite ideals, but upon definite plans for the practical amendment of the law of England. Where could a teaclier be found so acceptable to men of common sense as a lawyer who had studied the law of England more profoundly than had many Lord Cliancellors, and had studied it only with a view to removing its defects?"17

Therefore Bentham appealed to the conservative instincts of Englishmen. The reforms which he proposed aimed, not at revolution, but at giving a better security to liberty and property.

17 DrCEY, op. cit. supra note 2 , at 172-73. 
Secondly, Bentham's creed of utility had long been the accepted creed of many thinkers of many different political parties.

"Dr. Johnson, the moralist of the preceding generation, had admitted, and Paley, still the accepted English theologian of the day, had advocated, the fundamental dogma of Benthamism, that the aim of existence was the attainment of happimess. The religious teachers who touched the conscience of Enghishmen tacitly accepted this doctrine. The true strength of Evangelicalism did not, indeed, he in the fervour with which its preachers appealed, as they often did, to the terrors of hell as a sanction for the practice of virtue on earth, but the appeal was in fact a recognition of the principle of utility. ${ }^{18}$ When Bentham applied this principle to the amendment of the law he was in thorough harmony with the sentiment of the time; he gave no alarm to moderate reformers by applying to the appropriate sphere of legislation that greatest happiness principle which the public had long accepted as something like a dictate of common sense." 18

Therefore Bentham's creed appealed to a belief widely held by Englishmen of many different schools of thought.

Thirdly, Bentham's creed appealed to that distrust of state interference and that suspicion of socialistic measures which were old established instincts amongst the majority of Englishmen.

"During the long conflicts which have made up the constitutional history of England, individualism has meant hatred of the arbitrary prerogative of the Crown, or, in other words, of the collective and autocratic authority of the State, and has fostered the instinctive and strenuous effort to secure for the humblest Englishman the rule of law. Benthamism was, and was ultimately felt to be, little else than the logical and systematic development of those individual rights, and especially of that individual freedom which has always been dear to the common law of England." 20

Fourthly, and as the result of these three causes, Bentham's creed attracted men of all parties. Whigs and the followers of Peel, Place, and the trade unionists joined with Mill and the philosophic radicals in subscribing to some at least of the legal and economic ideas of Benthamism. ${ }^{21}$ This had an important effect on the extent of Bentham's influence. It would have been impossible to have accepted many of Bentham's detailed suggestions. But, because his ideas appealed to statesmen and lawyers of all parties, they were put into workable form and fitted into the fabric of English law by these

18 For an instructive parallel between the Evangelical and the Utilitarian movements, see Young, Victorian ENGLand (1936) 12.

10 DICEY, op. cit. supra note 2 , at 173-74.

20 Ibid. at 175-76.

21 Ibid. at 169-70. 
statesmen and lawyers. ${ }^{22}$ And so, such of his basic ideas as were practicable were accepted and adjusted to the technical needs of the English legal system.

Bentham's main object was the reform and the restatement of English law and the institutions of the English state, in order that they might be made to conform to the dictates of the principles of utility. In the pursuit of this objective he necessarily made incursions into topics on the border line of law and legal theory. It is for this reason that he has something to say on such subjects as philosophy, economics, and religion. But his writings on these topics were in the nature of by-products. It is generally agreed that Bentham was no philosopher. Mill said that he was no metaphysician, ${ }^{23}$ and Leslie Stephen said that he was weak in psychology and sociology, and unsatisfactory in ethics. ${ }^{24} \mathrm{He}$ never distinguished satisfactorily between law and morals. ${ }^{25}$ As Leslie Stephen points out, the elimination of motive, which is justifiable from the point of view of the legislator, takes all meaning out of morality. ${ }^{26}$ Bentham's philosophy will thus "do nothing for the conduct of the individual, beyond prescribing some of the more obvious dictates of worldly prudence, and outward probity and beneficence." 27 As Maine points out, ${ }^{28}$ he reasons about morals in the same way as he reasons about legislation, without any perception of the fact that the considerations applicable in these two spheres are fundamentally different. In economics he was for the most part a follower of Adam Smith. He anticipated the logical conclusions which the classical economists drew from Adam Smith's doctrines-though in some respects he departed from the strict laissez faire conclusions which some of those economists deduced from those doctrines. His speculations on religious matters were the logical consequences of his utilitarian philosophy, and show that he was as incapable of any real understanding of religion as he was of appreciating poetry. ${ }^{20}$ As Mill said, ${ }^{30}$ "Man is never recognized by

22 Ibid. at 170; see pp. 578-580, infra.

$231 \mathrm{MnL}$, op. cit. supra note 15 , at 335 .

24 1 STEpHzN, The ENGLISH UtHITARIANS (1900) 269-70.

25 HaxÉvy, op. cit. supra note 10, at 26-27.

261 STEPHEN, op. cit. supra note 24, at 258; cf. HALÉVx, op. cit. supra note 10, at 32-33.

27 I MuL, op. cit. supra note 15, at 363.

25 Lectures on the EarLy History of Institutions (3d ed. 1880) 400.

29 "Prejudice apart, the game of push-pin is of equal value with the arts and sciences of music and poetry. If the game of push-pin furnish more pleasure, it is more valuable than either." 2 BENTEAM, op. cit. supra note 5 , at 253; cf. 10 ibid. 583.

$301 \mathrm{MIII}$, op. cit. supra note 15, at 359. 
him as a being capable of pursuing spiritual perfection as an end...." Logically enough, he does not recognise such a thing as conscience, "as a thing distinct from philanthropy, from affection for God or unan, and from self-interest in this world or in the next." 31 These defects in Bentham's intellect are the natural consequences of his devotion to the study of legal theory and to the problems of law reform. As we shall now see, they help to explain both his defects and his merits in both these capacities.

\section{BENTHAM'S DEFECTS}

First, Benthain tries all institutions and all laws by one criterion and one standard-his own opinion as to what will make for the greatest happiness of the greatest number. His criterion and standard are those of the average man of his own day-"the respectable citizen with a policeman round the corner," 32 "the qualities obvious to an inhabitant of Queen's Square Place about the year 1800." 3 All speculations which failed to apply this criterion and this standard he ignored or ridiculed. As Mill says: ${ }^{34}$

"He had a phrase, expressive of the view he took of all moral speculations to which his method had not been applied, or (which he considered the same thing) not founded on a recognition of utility as the moral standard; this phrase was 'vague generahties.' Whatever presented itself to him in such a shape, he dismissed as unworthy of notice, or dwelt upon only to denounce as absurd. He did not heed, or rather the nature of his mind prevented it from occurring to him, that these generalities contained the whole unanalysed experience of the human race."

If we coinpare this attitude of mind with that of his great opposite, Blackstone, we can see that Blackstone often shows a greater knowledge of, and a greater appreciation for, those various prejudices and characteristics of the inen of his own day, of which those who would legislate effectively for them must take account. As I have pointed out, he realized that the principle of utility was only one amongst nany principles upon which the rules of a legal system is based; and that for the understanding of that system, and therefore for reforms which are practicable because they are based on understanding, account must be taken of these competing principles. ${ }^{35}$ Moreover

31 Ibid.

321 STEPHEN, op. cit. supra note 24 , at 314.

33 Ibid. at 300.

$341 \mathrm{MnLI}$, op. cit. supra note 15 , at 351 .

3512 HoLDSwORTH, op. cit. supra note 3 , at 734. 
it may well be that these competing principles have more truth in them than those who are blinded by a belief in a single principle will admit. ${ }^{36}$ Sydney Smith condensed the substance of Bentham's Book of Fallacies in his "Noodle's Oration."

"The noodle utters all the commonplaces by which the stupid conservatives, with Eldon at their head, met the demands of reformers. Nothing could be wittier than Smith's brilliant summary. Whigs and Radicals for the time agreed in ridiculing blind prejudice. The day was to come when the Whigs at least would see that some principles might be worse than prejudice. All the fools, said Lord Melbourne, 'were against Catholic Emancipation, and the worst of it is, the fools were in the right.' Sydney Smith was glad to be Bentham's mouthpiece for the moment: though, when Benthamism was applied to church reform, Smith began to perceive that Noodle was not so silly as he seemed." 37

Secondly, because Bentham had convinced himself that all institutions and all laws could be tried by one criterion and one standard, he emphasized the equality of all men. Such differences as existed he thought were due to difference in circumstances which could be easily removed, and could for many purposes be ignored. "Bentham's tacit assumption, in fact, is that there is an average 'man.' Different specimens of the race, indeed, may vary widely according to age, sex, and so forth; but for purposes of legislation, he may serve as a unit." 38 Whatever truth there may be in this assumption if confined to the men of a particular country at a particular time, it is obviously not universally true of men of all times and places. ${ }^{39}$ Yet this was the assumption made by Bentham and by all his followers.

Thirdly, because he made this assumption, he convinced himself that a science of law and legislation could be created which was governed by laws as invariable as those which governed the physical world. ${ }^{40} \mathrm{It}$ is for this reason that, as Maine said, ${ }^{41}$ Bentham and his

365 ibid. 480.

37 As quoted in 1 STEPHEN, op. cit. supra note 24, at 227-28.

38 Ibid. at 299. "What Bentham is teaching, under new formulae, is still a law founded on knowledge of the universal nature of man (Bentham uses the word in this sense), a law that can be used for the jurisprudence of all nations, a law whose language will serve as a glossary by which all systems of positive law might he explained, while the matter serves as a standard by which they might be tried." "HALÉvY, op. cit. supra note 10 , at 63 .

39 See p. 574, supra.

40 HaLévy, op. cit. supra note 10, at 29-30, 34.

41 Eardy Law ANd Custom (1883) 360. 
disciple Austin "sometimes write as if they thought that, although obscured by false theory, false logic, and false statement, there is somewhere behind all the delusions which they expose a framework of permanent legal conceptions which is discoverable by a trained eye, looking through a dry light, and to which a rational Code may always be fitted." It was a common fallacy of the utilitarians, and the logical consequence of their philosophy, that sciences of law and economics and even of history ${ }^{42}$ itself could be construed on the model of the exact sciences.

Fourthly, it followed, as we have seen ${ }^{43}$ that Bentham had very little use for history and its lessons. In fact he despised and distrusted it. He saw, as Dicey points out, ${ }^{44}$ that interest in history tends to shift the aim of legal study froin reform to research; that a study which enables explanation to be given of the reasons for abuses will provide arguments against their removal; and that historians tend to emphasize the dissimilarities between classes and nations, and to cast doubts on the paramount importance of those uniformities in the physical and mental characteristics of mankind which was the postulate of the utilitarian philosophy. This contempt and distrust for history meant that he ignored the accumulated experience of the race and iguored all those national characteristics which are the result of that history and that experience. But, as Mill points out, ${ }^{15}$ to reform effectively the laws and institutions of a nation, an understanding of its national character is essential:

"The true teacher of the fitting social arrangements for England, France, or America, is the one who can point out how the English, French, or American character can be improved, and how it has been made what it is. A philosophy of laws and institutions, not founded on a philosophy of national character, is an absurdity. But what could Bentham's opinion be worth on national character? How could he, whose mind contained so few and so poor types of individual character, rise to that higher generalization? All he can do is but to indicate means by which, in any given state of the national mind, the material interests of society can be protected; saving the question, of which others must judge, whether the use of those means would have, on the national character, any injurious influence."

42 The aim of Buckle's History of Civilization in England was "to fill the gap in the Utilitarian scheme by placing historical science upon a basis as firm as that of the physical sciences." 3 STEPHEN, op. cit. supra note 24 , at 347 .

${ }^{43}$ See p. 568, supra.

44 Op. cit. supra note 2 , at 457-60.

$451 \mathrm{MIIx}$, op. cit. supra note 15 , at 366 . 
It is to these four defects of Bentham's intellect that his greatest mistakes in the spheres of politics and law are due.

In his criticisms of the "matchless constitution" and of the established church he entirely ignores deep-seated national feelings and prejudices. His denunciation of Kings and the House of Lords did not represent the feelings of the intelligent majority; and, in fact, the nineteenth century has illustrated the usefulness of a King, and the need for a second chamber. He failed to see that annual Parliaments would make effective Parliamentary government impossible. His simple belief that a pure democracy would eliminate all sinister influences and would ensure enlightened government is logically absurd and has been proved to be absurd. It is logically absurd for the reasons given by Mill: ${ }^{46}$

"The numerical majority of any society whatever, must consist of persons all standing in the same social position, and having, in the main, the same pursuits, namely, unskilled manual labourers; and we mean no disparagement to them: whatever we say to their disadvantage, we say equally of a numerical majority of shopkeepers, or of squires. Where there is identity of position and pursuits, there also will be identity of partiahties, passions, and prejudices; and to give to any one set of partialities, passions, and prejudices, absolute power, without counter-balance from partiahties, passions, and prejudices of a different sort, is the way to render the correction of any of those imperfections hopeless; to make one narrow, mean type of human nature universal and perpetual, and to crush every influence which tends to the further improvement of man's intellectual and moral nature."

It was the great merit of that unreformed Parliament, which Bentham attacked, that the varieties in the franchise did provide a counterbalance to the prejudices of any single class. ${ }^{47}$ In fact, in 1818, Mackintosh, the representative of the Whigs, who had not yet been converted to the principle of the uniformity of the franchise, attacked Bentham's proposals on the ground that he had advocated a uniform and not a varied franchise. ${ }^{48}$

In his criticisms of the English legal system and of English law he entirely ignored the fact that it is work of the lawyers which has made both English law and Roman law great legal systems. He regards the activities of "Judge and Co." as merely harmful-though he admits that in the past they had supplied good legal material. He entirely failed to see that, however much the law may be codified,

46 Ibid. at 379-80.

4710 HoldsworTH, op. cit. supra note 3 , at 565-68.

48 HALÉVY, op. cit. supra note 10, at 418-19. 
whatever benefits may be derived from the codification of judgemade law, the work of interpreting the law, of systematizing its principles and rules, of applying the law to the facts, of elucidating the facts from conflicting evidence, needs the collaboration of learned lawyers. ${ }^{49} \mathrm{He}$ failed to see that the complexity of life, and therefore of the rules of law needed to regulate it, must increase with the complexity of civilization, so that his ideal of a code of substantive and adjective law, so simple that it could be understood by all, ${ }^{50}$ was ilusory. His scheme of administering justice through small local courts, in which the judge was not allowed to look at anything but the text of the enacted law, and his idea that the shortcomings of the Court of Chancery could be got rid of by scrapping the rules of equity, would have made short work with the English legal system. In fact, when he represented that system as a mere chaos studded with abuses, he was guilty of gross exaggeration. Mill's statement that Bentham found the philosophy of law a chaos and left it a science $e^{61}$ is a similar exaggeration. If English lawyers were destitute of any philosophy of law, how was it that they were able to make their legal system one of the great legal systems of the world? How did they manage in the eighteenth century to construct and work a constitution which was universally admired? How did they manage to think out for themselves wholly original ideas on the law of property, contract, and tort?

The truth is that English lawyers have never ignored legal theories, but they have declined, as Blackstone's Commentaries show, ${ }^{\text {t2 }}$ to be mastered by any one of them. They have preferred to build upon the stable foundation of the concrete facts of life and the needs of human beings, rather than upon the shifting sands of the conflicting theories of ingenious philosophers. Mill was nearer the truth when he said that "bad as the English system of jurisprudence is, its parts harmonize tolerably well together," so that it was difficult to reform particular abuses without creating difficulties in those parts of it which remained unreformed. ${ }^{53}$ The solution was not,

49 See MaINe, op. cit. supra note 28, at 49-50.

503 BENTEAM, op. cit. supra note 5, at 209; HAXÉVY, op. cit. supra note 10, at 378-79, 381-82.

51 MII, op. cit. supra note 15 , at 368 .

5212 HoldSWORTH, op. cit. supra note 3 , at 734.

53 "The truth is, that, bad as the English system of jurisprudence is, its parts harmonize tolerably well together; and if one part, however bad, be taken away, while another part is left standing, the arrangement which is substituted for it may, for the 
as he and Bentham thought, to reform it root and branch by the wholesale adoption of Bentham's suggestions, but to adopt the expedient which English lawyers in fact adopted, of using the talents of lawyers who were masters of the system, to make gradually the reforms which were needed in such a way that the changed rules were harmonized with the existing system. Bentham disapproved of this method of conservative reform; and if it be said that the fact that English lawyers pursued it shows their indifference to legal theory and the philosophy of the law, the answer is that it shows, not indifference, but an appreciation of the part which theory and philosophy on the one hand, and the conditions imposed by an existing system of law on the other hand, impose on law reform. Workable reforms can only be made by men who pay due attention both to theory and to the practical limitations imposed by the system of law which is to be reformed, by men who can not only appreciate the theory but who have sufficient knowledge of the existing system to work deductions from the theory into the technical fabric of that system. ${ }^{\text {54 }}$ It is well to remember that it was not only English lawyers who refused to accept Bentham's proposals in bulk. As M. Halévy has pointed out, ${ }^{55}$ his imfluence was greatest in those countries like Russia which had no legal tradition of their own. Lord Campbell, though he praised the Code Napoleon, said truly that it was "wholly

time, do more harm by its imperfect adaptation to the remainder of the old system, than the removal of the abuse can do good. The objection so often urged by lawyers as an argument against reforms, "That in so complicated and intricate a system of jurisprudence as ours, no one can foretell what the consequences of the slightest innovation may be,' is perfectly correct; although the inference to be drawn from it is, not (as they would have it to be understood) that the system ought not to be reformed, but that it ought to be reformed thoroughly, and on a comprehensive plan; not piece-meal, but at once. There are numerous cases in which a gradual change is preferable to a sudden one; because its immediate consequences can be more distinctly foreseen. But im this case, the consequences even of a sudden change can be much more casily foreseen than those of a gradual one." J. S. Mill's Preface to Bentham's Rationale of Judicial Evidence, 6 BENTHANr, op. cit. supra note 5, at 202-3.

54 "The bold vehement man who exposes an abuse has rarely the skilful, painful, dissecting power which expunges it.... A law reformer, in order that his work may be perfect, requires the conveyancing abilities. He must be able to bear in mind the wbole topic-to draw out what is necessary of it on paper-to see what is necessary-to discriminate the rights of individuals-to distinguish, with even metaphysical nicety, the advantage he would keep from the abuse he would destroy. He must elaborate enacting clauses which will work in the complicated future, repealing clauses which will not interfere with the comphicated machinery of the past." BAGEHOT, BTOGRAPHICAI STUDIES (2d ed. 1889) 73; cf. Brougham's criticism of this failing of Bentham in the introduction to his speech of 1828 on Law Reform, 2 SPEECHES (1838) 293-94.

65 Op. cit. subra note 10, at 296. 
insufficient to solve the vast majority of questions coming before the tribunals." 56

"Joseph Hume and other such ignorant coxcombs think that the whole law of England might be comprised in an octavo volume, and that all other books connected with the law might be burned. Were he to attend in the Palais de Justice, he would find the advocates and judges ... referring to the Civil Law, to the droit coutumier before the Revolution, to the works of Daguesseau and Pothier, and to a body of recent decided cases hittle less bulky than the Reports which load the shelves of an English lawyer." 57

These, then, are Bentham's defects as a legal philosopher and a law reformer. Let us now examine his merits which more than compensate for his defects.

\section{BENTHAM'S MERITS}

At the end of the eighteenth and the beginning of the nineteenth centuries the need for a thorough reform of English law, to bring it into conformity with the needs of a new age, was obvious. Its continuous and haphazard growth, and its "bit-by-bit" development" had resulted in a system marked by many archaic rules, by many legal fictions, and by many needless forms which were bidding fair to choke the sound principles and rules which it contained, and to make its administration so expensive that justice was in effect denied to the poor man. Mill's picturesque summary gives a substantially true picture of the result: ${ }^{59}$

"Hence the law came to be like the costume of a full-grown man who had never put off the clothes made for him when he first went to school. Band after band had burst, and, as the rent widened, then, without removing anything except what might drop off of itself, the hole was darned, or patches of fresh law were brought from the nearest shop and stuck on. Hence all ages of English history have given one another rendezvous in English law; their several products may be seen all together, not interfused, but heaped one upon another, as many different ages of the earth may be read in some perpendicular section of its surface-the deposits of each successive period not substituted but superimposed on those of the preceding. ... The whole history of the contest about trusts may still be read in the words of a conveyance, as could the contest about entails, till the abolition of fine and recovery by a bill of the present Attorney-General. ..."

561 Life of LoRd CaMpbeil (2d ed. 1881) 363.

57 Ibid.

58 See BAGEHOT, op. cit. supra note 54, at 284.

$591 \mathrm{MIIx}$, op. cit. supra note 15 , at 369-70. Good illustrations in the sphere of procedure will be found in the system of common law procedure ( 9 HoldsworTH, op. cit. supra note 3, at 247-62), and equity procedure (ibid. at 336-71). 
Bentham's principle of utility, and the method in which he applied it, was exactly what was required by those who set out to reform a system of law which had got into this condition. It gave reformers, as Maine said, ${ }^{60}$ "a distinct object to aim at in the pursuit of improvement"; so that, in that respect, it did for English law somewhat the same service as the theory of a law of nature did for Roman law. ${ }^{\text {bI }}$ Though Bentham's philosophy was defective, both his method and his test of utility applied a workable, and, Maine thinks, ${ }^{, 2}$ the only possible, criterion for the guidance of a legislature; and with this verdict Leslie Stephen agrees: ${ }^{: 3}$

"His [Bentham's] method involved a thoroughgoing examination of the whole body of laws, and a resolution to apply a searching test to every law. If that test was not so unequivocal or ultimate as he fancied, it yet imphed the constant apphication of such considerations as must always carry weight, and, perhaps, be always the dominant considerations, with the actual legislator or jurist. What is the use of you? is a question which may fairly be put to every institution and to every law; and it concerns legislators to find some answer, even though the meaning of the word 'use' is not so clear as we could wish."

In fact, it may be said that some of the defects of Bentham's philosophy helped to make him the more effective as a legal philosopher and a law reformer. He was, as Mill said, a "one-eyed man"; ${ }^{44}$ and, because he was a one-eyed man, he was able to state and explain his ideas and proposals with a clarity and force which a clearer view of the complexities and innate conservatism of human nature would probably have obscured. ${ }^{65}$ However that may be, the fact that the verdicts of Maine and Leslie Stephen are right is proved, first, by the services which Bentham has rendered to the philosophy of law and to men's ideas as to the machinery for its improvement; and,

60 ANCIENT Law (2d ed. 1863) 78.

61 "It is not an altogether fanciful comparison if we call the assumptions we have been describing [the assumptions made by the jurists who believed in a simple and symmetrical Law of Nature] the ancient counterpart of Benthamism. The Roman theory guided unen's efforts in the same direction as the theory put into shape by the Englislman; its practical results were not widely different from those which would have been attained by a sect of law reformers who maintained a steady pursuit of the general good of the community." Ibid. at 79.

62 Op. cit. supra' note 28 , at $399-400$.

631 STEPHENS, op. cit. supra note 24 , at 271 .

04 I Mns, op. cit. supra note 15 , at 357 .

65 HaLÉvy, op. cit. supra note 10, at 33-34. 
secondly, by the large number of reforms in the law which can be traced back to his ideas.

\section{Services to the philosophy of law and the machinery for its improvement}

(a) Philosophy. Because Bentham was determined to criticize abuses in all departments of the law, and to submit all laws to the test of utility, "he ... expelled mysticisin from the philosophy of law, and set the example of viewing laws in a practical light, as means to certain definite and precise ends." ${ }^{66}$ As Maine has said: ${ }^{87}$

“... if the Analytical Jurists failed to see a great deal which can only be explained by the help of history, they saw a great deal which even in our day is imperfectly seen by those who, so to speak, let themselves drift with history. Sovereignty and Law, regarded as facts, had only gradually assumed a shape in which they answered to the conception of them formed by Hobbes, Bentham, and Austin, but the correspondence really did exist by their time, and was tending constantly to become more perfect. They were thus able to frame a juridical terminology which had for one virtue that it was rigidly consistent with itself, and for another that, if it did not completely express facts, the quahifications of its accuracy were never serious enough to deprive it of value and tended moreover to become less and less important as time went on. No conception of law and society has ever removed such a mass of undoubted delusion."

Because Bentham was not only a critical thinker but a positive reformer who suggested remedies for the abuses which he criticized, he accomplished results far greater than any merely critical thinker has ever accomplished. The merely critical thinkers,

"took for their starting-point the received opinion on any subject, dug around it with their logical implements, pronounced its foundations defective, and condemned it: he began de novo, laid his own foundations deeply and finnly, built up his own structure, and bade mankind compare the two; it was when he had solved the problem himself, or thought he had done so, that he declared all other solutions to be erroneous."

It is for this reason that, as we shall see, so many of Bentham's suggested reforms have been adopted by the legislature. ${ }^{60}$

(b) Machinery. Bentham emphasized the fact that, to make the reforms which he advocated, direct legislation by a sovereign

68 I MIII, op. cit. supra note 15 , at 373.

67 Op. cit. supra note 28 , at 396-97.

68 I MIIx, op. cit. supra note 15 , at 338 .

${ }^{69}$ See pp. 584-586, infra. 
legislature was the only possible means. He not only "took up the theory of sovereignty where Hobbes had left it," 70 he made one considerable addition to it. Not only did he use it to define the State and the law, not only did he use it to prove that law enacted by a sovereign is the only law of which a legal system should consist, and that it attained its most perfect shape in a code, he also mamtained that it was the duty of the sovereign to be an active legislator in order to make the primciple of utility prevail throughout the legal system. "The formula of the greatest happiness is made a hook to put in the nostrils of Leviathan, that he may be tamed and harnessed to the chariot of utility." 71 Naturally, he emphasized the deficiencies of judge-made law, and both he and Austin poured scorn on Lord Mansfield's idea ${ }^{72}$ that the judges were better fitted for the work of law reform than the legislature. ${ }^{73}$ Bentham, as Dicey says, ${ }^{74}$ "forced the faith im scientific legislation upon the attention of a generation of Englishmen by whom its truth or importance was denied or forgotten." He made many valuable suggestions as to the manner in which this legislation should be drafted; ${ }^{75}$ and he not only invented the word 'codification,' but advocated the reduction of all law to the form of a scientifically constructed code.

These services rendered by Bentham to the philosophy of law and to the machinery of law reform largely outweigh his defects. We may not agree with all his criticisms of the English legal system and the English constitution; we may think that some of the rules of English law and some of the institutions of the English state which he called abuses were not abuses; we may not agree with some of his suggested reforms; we may doubt whether it is possible or desirable to restate all the law in the form of a code. At the same time, we cannot deny that a very large part of his criticisms were justified, that many of his suggested reforms are sensible, and that it is desirable to restate in the form of a code those parts of the law which are ripe for codification. As we shall now see, it is the merits of Benthan's principles, and the needs of the English legal system for a reformer convinced of the truth of those principles, and prepared

70 Porlock, History of the ScIence of PoLtrics (1890) 96.

71 Ibid. at 101.

72 Cited 12 HoldswortH, op. cit. supra note 3, at 551.

737 BENTHAN, op. cit. supra note 5, at 311. Austin's views on this matter are cited by Mill. 3 MmL, op. cit. supra note 15, at 252 .

74 Op. cit. supra note 2 , at 136.

75 11 HordsworTH, op. cit. supra note 3, at 375-77. 
to apply them in detail to all parts of the English legal system, that accounts for the large number of reforms in the law, which can be traced back to his ideas.

2. The reforms in the law which can be traced to Bentham's ideas

Bentham's principles had won some victories before 1832; but the major victories of his principles were won in the period which stretches from the Reform Act of $1832^{76}$ to the Judicature Acts of $1873^{7 \tau}$ and $1875 .^{78}$ That was the period when his philosophical, legal, and economic ideas were dominant. But his influence has lasted beyond this period, when the individualistic ideas of his followers were dominant, into the new age of collectivism and socialism. This is due partly to the fact that his ideas as to law reform were not dependent upon his fallacious political ideas or his fallacious economic ideas, partly to the intrinsic sense of many of his ideas as to law reform which have overcome the outworn prejudices which prevented their immediate realization, and partly to the fact that Bentham's individualism and distrust of the state were necessarily weakened by the fact that the application of his principle of utility to the government of the state had shown him that various social services such as health services, care of the poor, and national education, must be undertaken by the State. Let us look first at some of the reforms which can be traced back to Bentham's ideas, (a) in the period before, and (b) in the period after 1875 .

(a) John Hill Burton, who wrote the Introduction to Bowring's 1843 edition of Bentham's Works, said that the following suggestions for reform made by Bentham had then been wholly or partially carried out: ${ }^{70}$

"Reform in the Representative system. Municipal Reform in the abolition of Exclusive privileges. Mitigation of the Criminal Code. The abolition of Transportation, and the adoption of a system of Prison discipline adapted to reformation, example, and economy. Removal of defects in the Jury system. Abolition of Arrest in Mesne process. Substitution of an effectual means of appropriating and realizing a Debtor's property, to the practice of Imprisonment. Abolition of the Usury Laws. Abolition of Oaths. Abolition of Law Taxes, and Fees in Courts of Justice. Removal of the exclusionary Rules in [the law of] Evidence. Repeal of the Test and Corporation Acts, the Catholic Disabilities Acts, and other laws creating religious inequalities.

$762 \& 3$ WM. IV, c. 45.

$7736 \& 37$ VICT, c. 66.

7838 \& 39 VICT., c. 77.

${ }^{79}$ Advertisement to the Introduction, 1 BentEAM, op. cit. supra note 5 , at $3 \mathrm{n}$. 
Abolition or reduction of the Taxes on knowledge. A uniform system of Poor Laws under central administration, with machinery for the eradication of mendicancy and idleness. A system of traiming Pauper children, calculated to raise tliem from dependent to productive members of society. Savings Banks and Friendly Societies on a uniform and secure system. Postage cheap, and without a view to revenue. Post-office Money Orders. A complete and uniform Register of Births, Marriages, and Deaths. A Register of Merchant seamen, and a Code of Laws for their protection. Population Returns, periodical, and on a uniform system, with the names, professions, \&c., of individuals. The circulation of Parliamentary Papers as a means of diffusing the information contained in them. Protection to Inventions without the cumbrous machinery of the Patent Laws."

In the period between 1843 and 1875 many of these reforms were more fully developed. In public law the franchise was extended and voting by ballot was introduced. Trade was entirely freed, a system of national education was introduced, and an efficient system of local courts was provided. The judicial system was recast by the Judicature and Appellate Jurisdiction Acts; and, though law and equity were not fused, the courts of law and equity and of probate divorce and admiralty were amalgamated, and his idea of a "single seated" judge was adopted. The law of procedure and pleading was simplified, and facilities were provided for divorce. Companies with limited liability were introduced. Patronage was eliminated in the civil service, and its place was supplied by a system of competitive examination. Laws providing for the care of public health were enacted, and a machinery for their enforcement was provided. Great improvements were made in the classification and drafting of Acts of Parliament.

(b) In the period since 1875 more of Bentham's ideas have been realized. Complete democracy has been introduced, and the House of Lords has been shorn of its powers. Many of his suggestions for the reform of the law of real property had been adopted by the legislation of the mineteenth century; and those reforms have culminated in the Property Acts which have, amongst many other things, almost adopted his suggestion of "abandoning the heir at law to the Society of Antiquaries." Women have gradually been placed on an equality with men in public law; and married women have, contrary to Bentham's views, ${ }^{80}$ been given the same capacity in private law as unmarried women. Though his plan of a quasi-jury has not been adopted, his criticism of the jury as a tribunal to decide the facts in civil

801 BENTEAM, op. cit. supra note 5, at 356. 
cases has been given some effect by its disuse in many classes of civil cases, and the grand jury has been abolished. Though English law has not been completely codified, many important parts of it have been codified. His criticism of the law which attaches a sacramental efficacy to a seal is now generally accepted. Reforms in the theory of punishment have gone far beyond his suggestions; and in 1939 the principle of légitime was incorporated into English law.

The continued influence of Benthan's ideas upon legislation is due in large part to their merits. They were the logical results of his detailed application of that principle of utility which (whatever its deficiencies may be as a guide to morality) must always be the paramount consideration of a legislature. That so many of them were so quickly adopted is due to the fact that a small party of lawyers and political thinkers, who regarded Bentham as their oracle, summed up all the new ideas of this age-legal, political, economic, and religious-in the form in which he approved them, and made of them a coherent body of philosophical, political, economic, and religious doctrine. This group of philosophic radicals was a small and unpopular party; but they gave a coherence and definiteness to the new ideas upon all these topics which had been coming to the front in this age of transition. 